\title{
Вернуть государство
}

\begin{abstract}
MAGUN A. (ED.). (2020). THE FUTURE OF THE STATE: PHILOSOPHY AND POLITICS. LANHMAM: ROWMAN \&
\end{abstract} LITTLEFIELD. 296 P. ISBN 978-1-78661-483-4

\author{
Марк Белов \\ Стажер-исследователь, Центр фундаментальной социологии, \\ Национальный исследовательский университет «Высшая школа экономики» \\ Бакалавр, юридический факультет, Национальный исследовательский университет \\ «Высшая школа экономики» в Санкт-Петербурге \\ Адрес: ул. Мясницкая, д. 20, г. Москва, Российская Федерация 101000 \\ E-mail: markusabelov@gmail.com
}

«State theory is back». Такими словами начинает свою рецензию на книгу «The Future of the State: Philosophy and Politics» под редакцией Артемия Магуна американский политический теоретик Джоди Дин ${ }^{1}$. Это утверждение воодушевляет, ведь сегодня выходит сравнительно небольшое количество исследований, рассматривающих государство не только в исторической перспективе, но и переосмысляющих его на концептуальном уровне. Из русскоязычных работ, которые затрагивали бы данную проблематику, можно отметить сборник статей Европейского университета «Понятие государства в четырех языках», исследование О. В. Хархордина «Основные понятия российской политики», книгу М. М. Крома о рождении Московского государства и небольшую работу В. В. Волкова «Государство, или Цена порядка»². Из зарубежной литературы были выпущены переводы курса лекций о государстве Пьера Бурдье, масштабная работа Боба Джессопа, несколько книг антрополога Джеймса Скотта ${ }^{3}$.

* Публикация подготовлена в рамках исследовательского проекта Центра фундаментальной социологии НИУ ВШЭ «Этика солидарности и биополитика карантина: теоретические проблемы культурно-политических трансформаций в эпоху пандемий», реализуемого в рамках Программы фундаментальных исследований НИУ ВШЭ в 2021 году.

1. Dean J. (2020). Review: The Future of the State: Philosophy and Politics. URL: https://rowman.com/ ISBN/9781786614841/The-Future-of-the-State-Philosophy-and-Politics (дата доступа: 16.08.2021).

2. См.: Хархордин О. (ред.). (2002). Понятие государства в четырех языках. СПб.: Европейский университет в Санкт-Петербурге: Летний сад; Хархордин О. (2011). Основные понятия российской политики. М.: Новое литературное обозрение; Кром М. М. (2018). Рождение государства: Московская Русь XV-XVI веков. М.: Новое литературное обозрение; Волков В. В. (2018). Государство, или Цена порядка. СПб.: Европейский университет в Санкт-Петербурге.

3. См.: Бурдье П. (2017). О государстве: курс лекций в Коллеж де Франс (1989-1992) / Пер. с фр. Д. Кралечкина и И. Кушнарёвой. М.: Дело; Джессоп Б. (2019). Государство: прошлое, настоящее и будущее / Пер. англ. С. Моисеева под науч. ред. Д. Карасева. М.: Дело; Скотm Дж. (2о2о). Против зерна: глубинная история древнейших государств / Пер. с англ. И. Троцук. М.: Дело. 
Некоторые авторы указывают, что государство как аналитический объект вообще стало жертвой «ненадлежащего захоронения» ${ }^{4}$. Будучи во многом результатом деятельности средневековых юристов государство практически исчезло из оптики юридической науки, и на необходимость его концептуального обновления и изучения сегодня указывает сравнительно небольшое количество юристов-теоретиков $^{5}$. Социальные науки довольствуются эмпирическими исследованиями, где государство возникает не как самостоятельный предмет изучения, но лишь в связи с правоприменением, медициной или экономикой, выступая механистическим субъектом принятия решений. Во введении к книге отмечается, что по окончании холодной войны государство в политической науке стало рассматриваться в качестве самого главного института, имеющего незаменимые функции осуществления безопасности, управления макроэкономикой и благосостоянием, а также преследующего собственные корыстные интересы. Но все-таки государство оставалось институтом, порожденным обществом и призванным удовлетворять цели, поставленные обществом и международным сообществом, что явилось современной тенденцией автономизации, инструментализации и делигитимации государства (р. 4-5).

Большие теории государства ушли, но само государство осталось. Массированное наступление неолиберализма, проходившее под знаменем борьбы с государством, не ослабило его, но перестроило под нужды невыборных экспертов. Неолиберальное государство все еще государство, и в этом его ирония (р. 13). Именно размывание контуров государства, придание ему характера отсутствующего, но в то же время всегда присутствующего явления, готового вмешаться в жизнь, сделало его неуязвимым для интеллектуального «захвата». Но в период пандемии государство присутствует в нашей жизни более явно, чем когда-либо. Это проявляется в закрытых границах, различных ограничениях и карантинных мероприятиях. Если для одних возвращение государства стало возобновлением "утраченного» status quo, то есть обращением к сильному суверенному национальному государству ${ }^{6}$, то для авторов книги - это возможность радикального переосмысления способности государства быть демократичным. Именно задачу критического анализа государства и построения новой левоориентированной теории ставят перед собой авторы данного сборника (р. 3).

Указание на «левизну» не должно пугать и отталкивать читателя. Помимо левых мыслителей и теоретиков, которые, конечно, доминируют, в книге имеются

4. Aronowitz S., Bratsis P. (eds.) (2002). Paradigm Lost: State Theory Reconsidered. Minneapolis: University of Minnesota Press. P. xi.

5. См.: Назмутдинов Б. В. (2020). Критические концепции государства и их значение для российской юриспруденции: введение в проблематику // Lex russica. Т. 73. № 6. С. 122-138; Честнов И. Л. (2016). Постклассическая модель государственности // Известия высших учебных заведений. Правоведение. № 1. С. 62-79.

6. Зорькин В. Д. (2021). Возвращение государства: дееспособность власти проверяется в общенациональной беде. URL: https://rg.ru/2021/05/17/valerij-zorkin-deesposobnost-vlasti-proveriaetsia-vobshchenacionalnoj-bede.html (дата доступа: 27.07.2021). 
авторы, напрямую не связывающие государство с новой радикальной политикой или марксистской традицией. Так, например, Майкл Мардер говорит о государстве через кантовскую и аристотелевскую перспективы, раскрывая в самых абстрактных категориях, таких как место, отношение, субстанция, напряжение, способность разъяснить действительные политические проблемы (р. 15). Александр Филиппов подходит к рассмотрению государства в контексте международного права, обнаруживая взаимное влияние суверенного государства и международного порядка (р. 16). Но даже опираясь на одних и тех же мыслителей, левоориентированные авторы выстраивают критическую теорию государства совершенно по-разному. Это придает работе плюралистический характер, хотя и в рамках определенных координат.

Несмотря на различные воззрения авторов на государство, принципы его функционирования и его будущее, все они сходятся в одном: списывать государство со счетов рано. Как отмечает редактор сборника, авторов объединяет критический подход к превалирующему сегодня веберианскому инструменталистскому мышлению о государстве и желание предложить политическую альтернативу для будущего (р. 19). Остается только согласиться, что государство сегодня необходимо заново обнаружить и переосмыслить.

Формат рецензии не позволяет уделить внимание каждому автору, а потому, ни в коей мере не преуменьшая значимость и вклад других авторов, сконцентрируемся на текстах, открывающих теоретические и практические горизонты осмысления феномена сегодняшнего государства.

\section{Зачем государство?}

Британский социолог Филип Абрамс в своей статье 1977 года отмечал, что государство не есть реальность, стоящая за маской политических практик, но что оно само является маской, скрывающей политические практики ${ }^{7}$. Маска отводит взгляды особо заинтересованных, обманывая их своей внешней невозмутимостью, направленной на следование абстрактным принципам и ценностям. Это позволяет использовать понятие государства в самом широком политическом смысле, подминая под него и народ, и любое политическое объединение как таковое. В книге же, скорее, проводится апологетика государства как политического образования. Во вступительной части отмечается, что, ограничивая себя академическим значением, мы оставляем вакантным семантическое место государства-какполитии (р. 8). Для редактора сборника А. Магуна государство не просто предмет исследования и не ширма, скрывающая реальные политические процессы, но универсальная политическая форма объединения людей. Отношение к государству

7. Abrams P. (1988). Notes on the Difficulty of Studying the State // Journal of Historical Sociology. Vol. 1. № 1. P. 82 . 
как единству общества разрабатывалось философом в другой книге ${ }^{8}$. Государство по этой логике стоит очистить от неовеберианской и неомарксистской интерпретаций, отказывающих государству в позитивной модели организации политического пространства (р. 5). Магун предлагает следовать за Гегелем и заново ввести негативный элемент демократии в рамки государства, организовав их сосуществование (р. 9).

\section{Диалектика государства}

Проблемы, стоящие перед современным государством, должны быть решены диалектически (р. 14). Именно диалектический метод предлагает в своей главе Магун. Автор выводит генеалогию диалектики государства, начиная с Платона и заканчивая Карлом Шмиттом (р. 241-252). В этой генеалогии особо важными фигурами для диалектического метода современного государства, как представляется, являются Лейбниц, Христиан Вольф и Георг Еллинек. Лейбниц вскрыл парадокс сосуществования на одном уровне нескольких суверенитетов, стремящихся к совершенству и доминированию. Как один суверенитет может подчинять себе другой суверенитет (р. 245)? Магун считает, что это состояние показывает идеологическую реальность современности. Если суверенитет действительно существует, то нет никаких причин, почему к нему не может стремиться каждая субъективность (р. 245). В том числе и каждое государство, при условии, что оно выражает универсальную справедливость, пригодную для всего человечества ${ }^{9}$. Международное право разделяет национальный суверенитет и права человека, но оба они являются формами суверенитета как абсолютного права. Современное государство управляет корпорациями и негосударственными организациями, которые все больше похожи на изоморфные государства. Международное право ослабляет национальные суверенитеты, в то же время сохраняя их (р. 246), ведь субъектами международного права являются суверенные государства. Все это примеры взаимодействий и столкновений различных суверенитетов в ситуации отсутствия глобального суверена (р. 246). Это, по мнению автора, не должно вести к гоббсовской войне, но, скорее, к необходимости Civitas Maxima, идее мирового государства, без которого невозможно право, о чем писал Христиан Вольф (р. 246).

Георг Еллинек представлен в книге своей концепцией самоограничения государства. Сущность суверенитета, согласно немецкому юристу, состоит не только в верховенстве власти, но и способности к ее самоограничению через право. Магун пишет, что подобное решение возможно назвать диалектическим в той мере, в какой оно позволяет обнаружить напряжение между всемогущим государством, принципом ограниченной власти и автономией субъекта. Автор тут же замечает, что порой подобные правовые самоограничения приводят к невозможности де-

8. Магун А. В. (2011). Единство и одиночество: курс по политической философии Нового времени. М.: Новое литературное обозрение. С. 13.

9. Бибихин В. В. (2005). Введение в философию права. М.: Институт философии РАН. С. 34. 
лать что-либо, как, например, в ситуации развала СССР (р. 250). Чтобы прийти к действительно диалектической модели, Магун дополняет концепцию Еллинека указанием, что самоограничение происходит с целью наделения другого субъекта большими правами, а после соединяет идею самоограничения с чрезвычайным положением К. Шмитта. Получается следующая схема: 1) государство самоограничивает себя с тем, чтобы наделить протестную группу правами; 2) протестная группа восстает против государства, вводится чрезвычайное положение; 3) государство возвращает себе власть, но только для того, чтобы ограничить власть восставших с целью уравнения субъективностей. В результате это не восстановление предыдущего порядка, но отрицание отрицания (р. 252). В этой схеме мы видим выражение диалектики государства на национальном уровне: борьба многих субъектов, стремящихся к суверенитету (Лейбниц); наличие суверена, определяющего право (Вольф); самоограничение, ведущее к установлению иного качественного состояния (Еллинек и Шмитт).

Диалектический метод, на первый взгляд репрессивный, необходим для решения вопроса неудач протестных движений. По мнению автора, большинство социальных движений противоречивы и имеют скорее деструктивный, нежели конструктивный характер. Они находятся в диалоге с государством, но не стремятся воссоздать политию (р. 255). Демократия же, указывает философ, создается не движением снизу, но пересечением гражданского участия и самоорганизации с отзывчивостью и демократическими интересами руководящих органов (р. 257). В тех странах, где этого пересечения не происходит, мы можем наблюдать либо отмену демократии, либо гражданскую войну.

Еще одним важным элементом диалектики государства выступает концепт репрезентации. Правительства XIX века пытались исключить персональный фактор с помощью ротации официальных лиц, но сама идея выборов представителей делала политику более персонифицированной (р. 261). Впрочем, концентрация на личности выборного политика началась с того момента, как победила точка зрения федералистов о том, что представитель должен превосходить своих избирателей ${ }^{10}$, а в саму федеральную конституцию США вошла сильная президентская власть и иные централизующие элементы ${ }^{11}$. Сегодня мы наблюдаем начало коллапса репрезентативной политики как таковой. В демократических системах появляются недостойные политики, пытающиеся быть суверенами ${ }^{12}$, а протестные движения, ранее поддерживаемые харизматичным лидером, затухают, будучи обезглавленными. Репрезентация позволяет А. Магуну выявить диалектику, о которой говорилось абзацем выше. В демократическом государстве все лица наделены полномочиями по усмотрению. Правительство авторизируется обществом так

10. Замятин А. (2021). За демократию: местная политика против деполитизации. М.: Издательские решения. С. 93 .

11. Хархордин О. В. (2021). Республика. Полная версия. СПб.: Европейский университет в СанктПетербурге. С. 96.

12. Newman S. (2019). Political Theology: A Critical Introduction. Cambridge: Polity Press. P. 102. 
же, как и должностные лица и представители социальной власти авторизируются правительством. При этом эти назначения происходят в определенных пределах (р. 262). Здесь отражена и идея столкновения суверенных субъектов, обладающих властью, и концепция самоограничения.

Однако нам кажется, что самым слабым звеном в этом диалектическом движении остается общество. В контексте государственного устройства все же лучше использовать конституционное понятие народа, если мы, конечно, не говорим о строительстве политии с нуля. Народ как категория является юридической фикцией так же, как и органы власти, которые он авторизует. Но фикцией самой слабой, поскольку ее стабильность напрямую зависит от практик участников общества, в отличие от институтов государственной и полицейской власти, имеющих силу за счет социальных представлений и объективации. Получается, что современный Левиафан состоит вовсе не из тел подданных, но из юридических абстракций, в которых растворяется личность в силу налаженности бюрократического процесса. Эти юридические маски на каждом из уровней власти, как верно указывает Магун, действительно имеют определенную долю суверенитета, направленного на правоподдержание существующего порядка. В. Беньямин проводил разграничение между правоустанавливающим и правоподдерживающим насилием. Первое может устанавливать для себя правовые цели, в то время как второе подлежит ограничению ${ }^{13}$. Но в правовой ситуации отсутствия какой-либо ясности эта грань стирается ${ }^{14}$, позволяя расширять границы правопорядка. Пандемия является наглядной иллюстрацией подобного положения. Полномочия по введению ограничений и проведению вакцинации, хотя и в законном порядке, были спешно отданы ведомствам субъектов Федерации, позволив этим медицинским суверенам заниматься правоустанавливающей практикой. Постановления главных санитарных врачей и губернаторов субъектов создали новые порядки функционирования практически всех предприятий. Пандемия вообще раскрыла возможности волюнтаристской перекройки правовой реальности. Оказаться в новом правовом порядке нам еще предстоит. Подобным образом проявляется бессознательное государства (р. 262).

Не может остаться без рассмотрения вопрос соотношения государства и международной системы. Диалектика государства и международного порядка серьезно усложняет идеальную картину Вестфальского мира. Упования либералов и постмодерновых левых на глобальное правительство разбились о реальность реакции государств и их империалистского расширения (р. 265). Выход из ситуации, когда абстрактная правовая рамка не воспринимает суверенные структуры национального и международного сообщества, видится автору в создании международной делиберативной демократии для всех гражданских автономных объединений (р. 266). Но достигнуть полного решения противоречий возможно только

13. Беньямин В. (2012). К критике насилия / Пер. с нем. И. Чубарова // Беньямин В. Учение о подобии: медиаэстетические произведения. М.: РГГУ. С. 77.

14. Там же. С. 78. 
в мировом федеральном государстве (р. 269), основанном на праве субъектов, а не правилах или нормах (р. 268). Магун предпринимает попытку переосмысления всего глобального устройства мира, демонстрируя на последних страницах своего текста правовую систему государства будущего (р. 271-275). Состоятельность подобного предприятия следует оставить на суд читателя. И хотя автор отмечает, что в одной статье нельзя решить все конфликты, не предъявляя каких-либо претензий, поставим несколько вопросов для дальнейшего размышления.

Подобный проект, если он рассчитан на реальность, потребует предварительного этапа фундаментального философского переосмысления права и еще большей практической работы по перестройке правовых институтов. Даже если предположить, что эта стадия будет пройдена, следует спуститься с уровня философского устремления на уровень практики, тем более что автор сам призывает считаться с реальностью. Почти невозможно представить себе ситуацию, в которой суверенные государства пойдут на столь масштабные шаги по сближению. Кроме того, подобное сближение требует не только политической воли, но и проникновения в идеологические основы каждого правопорядка, ведущего к разрушению социально-правовой действительности. Потенциал этого деструктивного для социального порядка действия имеют самоорганизующиеся движения, коим Магун отказывает в эффективности. Философ утверждает, что любой субъективности свойственно стремление к суверенности (р. 246), то есть стремление к утверждению примата собственной власти над всеми другими властями. В связи с этим вспомним предупреждение В. В. Бибихина: «Если весь мир станет одним государством, этого соревнования уже не будет, и придется бояться, что, если всемирное государство пойдет путем неправа, не будет реальной силы для его исправления» ${ }^{15}$. Радикальная негативность оставляет зазор и для подобного развития истории.

При всем том статья Магуна - смелый и интересный интеллектуальный вызов, а диалектический метод, предложенный философом, способен раскрыть неожиданные стороны функционирования государства. Помимо этого, проект мирового государства расширяет грани мышления о мире, что наверняка способно вывести на неожиданные социально-политические эксперименты.

\section{Феноменология государства}

Открывающая книгу глава Майкла Мардера самая философично нагруженная, а потому краткое ее изложение без потери смысла и внутренней логики представляется проблематичной задачей для рецензии. Выделим некоторые моменты, раскрывающие неожиданные аспекты бытия государства.

Философ предлагает отказаться от рассмотрения государства как «искусственного человека» и исследовать его через категории Аристотеля и Канта. По мнению

15. Бибихин. Указ. соч. С. 35 . 
автора, это позволяет прочертить контуры политического образования, а само «категориальное мышление» обращается к основаниям государственной данности в политическом восприятии. В этом смысле то, что предпринимает Мардер, является феноменологической критикой государства (р. 25-26). Важно обозначить, что в данной главе автор употребляет «the state» не только как государство, но и в качестве значения «to stand», то есть «the state» также означает позицию, позу (р. 26).

Государство как позиция оказывается необходимостью в силу возможности самой политики, потому все оппозиционные движения занимают позицию по отношению к положению, которое не только принадлежит государству, но и является им (р. 28). Но такие социальные движения могут быть интерпретированы иначе. Современные анархистские теоретики предполагают, что люди в движениях по типу «Оссиру» смотрят не на государство, но друг на друга, тем самым воплощая стремление к автономной самодостаточной жизни ${ }^{16}$ и избегая поглощения государством. Независимо от оценок, которые дают этим группам разные идеологии, чтобы узнать истинное самоощущение данных движений, необходимо обратиться к их качественному, а не спекулятивному анализу ${ }^{17}$.

Важным понятием для переосмысления международного порядка становится «сообщество». Сообщество - это взаимоотношения возможности действовать и подвергаться воздействию (reciprocity of acting and being acted upon) (p. 29). С этой точки зрения «международное сообщество» неправильный термин для определения существующих международных отношений. Многие субъекты международного права просто не способны действовать, но постоянно оказываются под воздействием. Граждане также оказываются зависимы от государства, поскольку оно считается причиной их положения. Положение граждан напрямую зависит от положения государства (р. 30). Примером могут служить негативные для населения эффекты от международных санкций. Будучи направленными против определенных государств как субъектов международного права, а не форм политического объединения индивидов, они зачастую приводят к ухудшению положения государства именно как формы политического объединения, поскольку люди оказываются подчинены и зависимы от действий государства как субъекта, хотя они и не определяют его поведения на международной арене.

Как возможно решить эту проблему? Философ обращается к раннему Марксу, напоминающему, что государство является стабилизацией конфликта - не его подавлением, но направлением. Условия борьбы, присущие республике, формализуются в государстве, однако проблема начинается в тот момент, когда государство отрывается от вещи, которую формализует, то есть от республики, претендуя на

16. Ньюман С. (2021). Постанархизм / Пер. с англ. О. Л. Грабовской. М.: РИПОЛ классик. С. 49.

17. Хотя в России не замечается движений как «Оссиру», представляется, что исследования Лаборатории публичной социологии могут наметить курс выявления мотиваций и механизмов функционирования протестных движений, а также самоощущений их участников (https://publicsociology.tilda. ws/russia; дата доступа: 30.07.2021); Журавлев О., Ерпьлева C. (2021). Что нового в новых протестах? URL: https://www.opendemocracy.net/ru/chto-novogo-v-novyh-protestah-erpyleva-zhuravlev/ (дата доступа: 30.07 .2021$)$. 
руководство жизнью (р. 30-31). Следовательно, государство необходимо вернуть к субстантивирующей стабилизации, где оно не будет оторвано от республики. Отношения будут строиться на возможности действовать и подвергаться воздействию. Государство, следуя кантовской категории количества, должно видеть единство в множественности, тем самым упорядочивая разрозненные реальности различных движений. Эти реальности не могут быть идентичны, но должны быть организованы государством как совокупностью для возможности политики вообще (p. 36).

\section{Международный порядок юридических пространств}

Статья Александра Филиппова логически разделена на две части. В первой автор обсуждает восприятие государства в качестве территориального образования, эксклюзивно связанного с пространством, а во второй разбирает вопрос взаимодействия суверенитета с внешней силой международного права.

\section{Эксклюзивная территория}

Социолог начинает с указания на то, что сегодня территория как отличительный признак государства теряет свое значение (р. 40). Он соглашается с критикой других авторов, указывающих на ошибочное восприятие государства как «пространственного контейнера», однако не разделяет их уверенности в том, что территория по-прежнему является основой геополитических взаимодействий. Для тех, кого Зигмунт Бауман называл «глобальной элитой», государственные границы исчезают (р. 41). Пандемия коронавируса показала, что границы важны даже для «глобальной элиты», но важны в той степени, и это подчеркивается исследователем, в какой старый концепт территории может работать в новых условиях. Да, границы снова проявили себя, но только для людей, то есть для тел в пространстве, доступных оптике государства. В первую очередь такими телами являются граждане, которые в период пандемии должны находиться внутри пространства государства, а потому границы становятся медиумом, воспринимающим деление между внутренним и внешним (р. 42). Но важность пространства государства заключается не только во вновь актуализировавшихся границах, но и в эксклюзивности места государства на физической территории. Приводя аргументы К. Шмитта и Г. Зиммеля, А. Филиппов показывает, что на одной территории может существовать лишь одно государство, в то время как иные формы ассоциаций могут быть взаимопроникающими, поскольку они связаны с пространством не эксклюзивно (р. 44).

Здесь в фокус ученого попадает международное право, бросающее вызов логике внутреннего и внешнего, определяемой суверенитетом государства. Относительная слабость международного права подчеркивает приоритетность государства, но в то же время превосходящая сила международного права указывает 
на отступление государства. Международное право слабо, потому что государство-суверен не признает никого выше себя на своей территории и обеспечивает подчинение закону через легитимное насилие. Сила же международного права заключается в том, что оно универсально и независимо от воли суверена, живет дольше, чем суверенное государство, автономно от наций, признающих его. Тем самым международное право обеспечивает общие основания для заключения соглашений (р. 45-46). Такими общими и автономными от воли государств нормами сегодня являются нормы jus cogens, признающиеся международным сообществом как нормы, отклонение от которых недопустимо ${ }^{18}$. Примерами могут служить запрет пыток и рабства ${ }^{19}$, геноцида ${ }^{20}$.

Эти нормы не существовали сами по себе, но явились результатом научения всего мира горьким опытом XX века. На этом уровне виден фундамент этих норм, хотя и признанных абсолютными, а именно соглашение, заключенное между субъектами, то есть государствами. Вслед за немецким юристом Генрихом Трипелем автор проводит разделение между договором (contract), где страны преследуют собственные корыстные интересы, и соглашением (agreement), в котором интересы разных государств совпадают. В свою очередь, это поднимает проблему того, что основания для значимости таких соглашений не могут быть чисто юридическими, ведь для того, кто не является участником, подобное соглашение не имеет силы (p. 48-49). Отметим, что упомянутые нормы jus cogens считаются универсальными и обязательны абсолютно для всех, а не только для участников конвенций. Это, к сожалению, не мешает некоторым государствам, даже являющимся участниками конвенций, нарушать данные предписания, обосновывая свои решения суверенной, то есть как раз внутренней волей. Как без повторения ошибок прошлого возможно обеспечить взаимопроникновение международного и национального права, тем самым удостоверившись в соблюдении соглашений?

\section{Суверенитет как обязанность}

В будущем возможна ситуация, когда люди более не захотят придерживаться доктрины того, что должно быть правительство, одновременно превосходящее другие власти и независимое по отношению к зарубежным правительствам. Предпосылками к этому, как отмечается, являются права человека, ради которых может быть нарушен суверенитет. Это ведет Филиппова к утверждению, что в эру глобализации вместо государства должны действовать иные силы, выполняющие роль полицейского надзора, а перед глобальными миром и правом как территориальность, так и суверенитет релятивизируются (р. 50). Более того, исследование

18. Ст. 53 Венской конвенции о праве международных договоров. URL: https://www.un.org/ru/ documents/decl_conv/conventions/law_treaties.shtml (дата доступа: 30.07.2021).

19. Ст.ст. 4-5 Всеобщей декларации прав человека. URL: https://www.un.org/ru/documents/decl_ conv/declarations/declhr.shtml (дата доступа: 30.07.2021).

20. Конвенция о предупреждении преступления геноцида и наказания за него. URL: https://www. un.org/ru/documents/decl_conv/conventions/genocide.shtml (дата доступа: 30.07.2021). 
Лорен Бентон «A Search for Sovereignty» проливает свет на тот факт, что границы Европы были проницаемы для правовых практик, путешествовавших вместе с должностными лицами, купцами и моряками (р. 51-52). Иными словами, суверенитет и оппозиция, проходящая по границе внутреннего/внешнего, всегда были относительны.

В связи с этим Филиппов не обходит стороной дискуссию о конституционализме. Конституционализм - это попытка привнести единение и порядок в мировое пространство, авторитетно установив определенную иерархию государств и норм на международном уровне (р. 52-53), что напрямую ограничивает суверенитет государства. Проблемой является отсутствие международного органа, способного удовлетворить критериям этой концепции и дать мировую конституцию. Однако мировая стабильность, то есть соблюдение норм, может достигаться за счет ответственности государств так же, как за счет государственных санкций достигается стабильность правопорядка на национальном уровне. Концепция «обязанность защищать», или responsibility to protect (R2P), обязывает государства защищать своих граждан внутри государства от массовых преступных злодеяний. Суверенитет в этом смысле трансформируется и более не означает первенство одной власти перед другими, но накладывает обязательства и действует в двух направлениях: во внутреннем и внешнем (p. 53). R2P позволяет другим государствам нарушать границы государства, не исполняющего внутреннюю функцию суверенитета по защите своих граждан, то есть устраивающего геноцид, военные преступления, преступления против человечности.

Не пытаясь дать какие-либо этические комментарии, укажем на некоторые сложности, которые несет в себе возможность вмешательства во благо прав человека. $\mathrm{R} 2 \mathrm{P}$ никогда не применялось прямо и не имеет под собой правового основания на уровне международных соглашений. Полномочия по военному вмешательству в случае угрозы миру при недостаточности мер, не связанных с использованием вооруженных сил, согласно главе VII Устава ООН, находятся в ведении Совета Безопасности и могут осуществляться на основании статьи 42 Устава $^{21}$. Данная статья практически никогда не реализовывалась, а миссии, которые de facto имели применение вооруженных сил $\mathrm{OOH}$, de jure оформлялись как гуманитарные на основании главы VII Устава в общем ${ }^{22}$. Кроме того, гуманитарные интервенции и подобное вмешательство в суверенитет несут в себе неразрешенные проблемы символического характера. Французский антрополог Дидьер Фассен, рассматривая гуманитарную помощь в качестве дара, указывает, что жертвы, получая ее, не могут отказаться, тем самым встают в позицию должников ${ }^{23}$. Политика жизни, осуществляемая акторами гуманитарной помощи, становится в оппозицию поли-

21. Ст. 42 Устава OOH. URL: https://www.un.org/ru/about-us/un-charter/full-text (дата доступа: 30.07.2021).

22. См., например: п. 10 Резолюции 794 (1992), принятой Советом Безопасности на его 3145-м заседании 3 декабря 1992 года. URL: https://undocs.org/ru/S/RES/794(1992) (дата доступа: 19.08.2021).

23. Fassin D. (2012). Humanitarian Reason: A Moral History of the Present. Berkeley: University of California Press. P. 233. 
тике смерти криминального государства, что возвращает нас к манихейскому дискурсу вечной борьбы сил добра и зла ${ }^{24}$. Гуманитарная помощь также рассматривается некоторыми исследователями в качестве этической гегемонии, поскольку она позволяет дарителям поучать и судить получателей ${ }^{25}$.

Филиппов приходит к выводу, что суверенные государства сталкиваются не с вещью другого или более высокого порядка, но с чем-то менее конкретным. Возможно, указывает автор, новый порядок международного права будет не «контейнером», но реальностью практик и решений или регуляторной системой более сильной, чем государства (р. 55). Действительно, проведенное исследование убедительно доказывает, что внутреннее и внешнее всегда было взаимопроникаемо, а сегодняшний мировой порядок строится на взаимной ответственности государств перед друг другом. Однако обозначенное движение к конституционализму или регуляторной системе, превышающей силы государства, выглядит спорным. Первичными субъектами международного права ipso facto являются государства и в некоторых случаях народы и нации. Первичные субъекты способны объединяться в производные субъекты, коим, например, и является ООН. Действия ООН определяются условностями государств, а в случае угрозы миру лишь 15 ее членами. Такое состояние не выглядит чем-то «менее конкретным», поскольку напрямую зависит от волеизъявлений государств как основных участников международных отношений. Через такую линзу международный порядок видится хрупким и неустойчивым и, возможно, именно в этом смысле «менее конкретным».

\section{Революционизируя государство}

Панайотис Сотирис начинает свои размышления с критики левых радикальных движений ${ }^{26}$, отказавшихся ставить вопрос о политической власти. Политические движения снизу, оказывающие давление на государство, парадоксальным образом от него дистанцируются, поскольку не пытаются захватить гегемонию политической власти. Власть же эта, по мнению автора, по-прежнему материальна, а потому является неизбежным вопросом для тех, кто пытается думать о радикальной политике (р. 9о). Причиной, по которой левые отошли от вопроса государственной власти, становится неолиберальная контрреволюция, антигосударственная риторика которой привела к идеализации государства со стороны левых. Подобный уход от критики государства закрывает возможности обсуждения более радикальной социальной демократии, которая может быть достигнута новой критикой и пониманием работы современного государства (р. 96).

24. Ibid. P. 234.

25. Hattori T. (2003). Giving as a Mechanism of Consent: International Aid Organizations and the Ethical Hegemony of Capitalism // International Relations Vol. 17. № 2. P. 153-173.

26. «Радикальный» здесь и далее следует понимать в смысле проекта радикальной демократии Э. Лакло и Ш. Муфф. 
Для этого автором привлекается теория Антонио Грамши, демонстрирующая, что государство не просто аппарат власти, но комплекс практических и теоретических действий, с помощью которых правящий класс добивается поддержки тех, над кем он правит. Сотирис также обращается к концепту «революционизации» государства, взятому у Никоса Пуланзаса. Он отмечал, что государство - это не сущность, но конденсация классовых отношений, а его функции по репродукции социальных отношений (экономических, политических, идеологических) вовсе не нейтральны и не были испорчены правящим классом, но вписаны в саму структуру государства. Рабочий класс не может просто занять место буржуазии на уровне государственной власти, поскольку в таком случае отношения политического доминирования продолжат воспроизводиться, - рабочий класс должен радикально трансформировать (to «smash») государство в самой его структуре (p. 92). Забытый сегодня российский и советский юрист, марксист М. А. Рейснер предупреждал, что процесс завоевания политической власти начинается еще под влиянием современного фантазма государства с его институтами, что приводит не к утверждению диктатуры пролетариата, а к диктатуре пролетарской канцелярии ${ }^{27}$. Это могло бы дополнить размышления Сотириса о том, что изменения должны проходить не только в психике государственных служащих, но и в материальных процессах воспроизводства государства: конституционных соглашениях, праве и институциональной памяти (р. 99).

Каким же образом должна протекать революционизация государства? Несмотря на то что вначале автор критикует самоорганизующиеся радикальные движения, именно в них он видит возможность революционизации. Они бросают вызов ограничениям классовой борьбы, материализованным в структуре государственного аппарата. Подобные движения, по мнению Сотириса, создают двоевластие, выходящее за пределы ситуации накануне революции, о которой писал В. И. Ленин. Это более не вопрос временного кризиса, но возникновение новой формы политической борьбы (р. 98). Как нам кажется, самым ярким проявлением такой формы двоевластия за последнее время была Автономная зона Капитолийского холма. И хотя трудно представить, что подобные формы самоорганизации способны на долгое существование, они оказываются процессом коллективного эксперимента с новыми политическими и социальными конфигурациями, основанными на борьбе и самоорганизации, возникающими задолго до номинального захвата власти (р. 102). Такие практики возбуждают фантазию и возвращают в политику утопическое мышление, выходящее за пределы существующей реальности ${ }^{28}$, а значит, дающее возможность коренного изменения действительности.

Сотирис отмечает, что демократия означает борьбу и экспериментирование, а не простое выражение мнений (р. 101), следовательно, необходимо отказаться

27. Рейснер М. А. (1908). Теория Л. И. Петражицкого, марксизм и социальная идеология. СПб.: Типография товарищества «Общественная польза». С. 147-148.

28. Бертоло А. (2018). Субверсивное воображение // Бертоло А. Оставим пессимизм до лучших времен: переосмысляя анархизм. М.: Черный квадрат. С. 122. 
от мифа о коммунизме как об обществе всеобщего примирения ${ }^{29}$. В этом автор видит проблему сегодняшних движений, построенных на мнимой горизонтальности, ведущей к неспособности принятия какого-либо решения (р. 105-106). Политические организации как лаборатории должны быть более демократичными, эгалитарными и открытыми обществу вокруг них (р. 105), но подобные ценности не отменяют вопроса власти, только после возвращения которого возможна подлинная пересборка самой структуры государства.

\section{Коммунистическая теория государства}

С очевидностью для всех пандемия COVID-19 показала, что рынок не может справиться с масштабными катастрофами просто потому, что способы решения глобальных проблем действуют против главной логики рынка - извлечения прибыли. Как подчеркивает Агон Хамза в главе «The March of God or the Žižekian Theory of the State», не только рынок, но и одно государство не способно справиться с подобными глобальными угрозами, а значит, абсолютно необходима международная кооперация (р. 187). П. Бурдье, пересказывая книгу Абрама де Сваана об эпидемиях, предполагал, что, возможно, именно от эпидемий стоит ждать появления универсального государства, ведь у всех правительств будет общий интерес - ограничение распространения опасности ${ }^{30}$. И действительно, все государства, несомненно, преследовали эту цель, вот только методы оказались отнюдь не кооперативного характера. Обоюдное закрытие границ натолкнуло государства не на мысли о хрупкости и непредвиденности человеческого горизонта, но на вульгарную демонстрацию медико-технологических успехов на фоне растущего количества смертей. Гонка в разработке вакцины привела к тому, что одни ее виды признаются на одной территории и недействительны на другой ${ }^{31}$. Вводятся новые ограничения, затрагивающие как права граждан государств, так и иностранцев. Пандемия скорее поспособствовала еще большей сегрегации международных субъектов, нежели их объединению. И хотя меры, как отмечено в предисловии, действительно были направлены против бизнеса (р. 1), они не дали ощутимого результата со стороны социальной поддержки населения, которая в некоторых странах была ничтожно мала. Опасения Хамзы, что новая реальность будет намного мрачнее, вполне обоснованны (р. 188).

Главной целью текста в связи с несостоятельностью рыночной системы перед лицом катастроф является попытка помыслить коммунистическое государство. Философ выдвигает нетривиальное утверждение, что причина, по которой про-

29. Муфб Ш. (2013). Радикальная демократия и агонистическая политика: рецептура гегемонии для любой власти - для власти современной. URL: http://gefter.ru/archive/10569 (дата доступа: 31.07.2021).

30. Бурдье. Указ. соч. С. 651. Бурдье в лекции проводит аналогию между эпидемией и авариями на AЭC.

31. Это состояние может быть охарактеризовано как «A state of medical war» в терминологии Жижека, на которого ссылается автор (р. 188). 
валился социализм в XX веке, заключалась не в терроре, авторитарных режимах или посягательстве на достоинство человека, но в самом социализме (p. 189). Социализм не упразднял собственность на пути к коммунизму, но лишь менял модус ее существования с частного на государственный, оставляя нетронутыми социальные отношения, в которых собственность функционировала (р. 190). Логика понятна и аналогична тезису о структурном изменении государства. Это подчеркивает и сам автор. Нельзя преодолеть капитализм, не переосмыслив государственную форму (р. 189). Недостаточно захватить государственный аппарат, дожидаясь, пока пройдет промежуточная стадия и установится коммунизм, поскольку эти стадии становятся нескончаемыми и рассматриваются как фетишистская замена предполагаемой утопии (р. 191). Бесконечное количество этапов позволяет искусственно удлинять путь к предполагаемой цели, не совершая при этом никаких реальных изменений. Поэтому, пишет теоретик, следует отказаться от убеждения, что наши нынешние поступки смогут быть легитимизированы с позиции более высокой стадии. Не существует ничего, кроме нынешней стадии (р. 191). Это заключение, по нашему мнению, сближает Хамзу с постанархистами, развивающими принцип онтологической анархии, позволяющий избавиться от детерминированности действия ${ }^{32}$. Мировое божество может умереть, а дальнейшая история зависит от нас (р. 20о). Еще большее сближение можно обнаружить в отказе от эссенциализации человека. Критикуя убеждение, что при социализме пропадают ревность, зависть и ресентимент, Хамза задает вопрос: а что, если новые социальные отношения продолжат строиться на этих чувствах? Это те угрозы, которые следует учитывать при мышлении о «более высокой стадии» (р. 192).

Способ преодоления мышления о стадиях видится в реабилитации решающего понятия в философской системе Гегеля: государства (р. 192). Перечитывая философию права и науку логики Гегеля, Хамза приходит к выводу, что диалектический процесс не заканчивается на примирении антагонизмов, но, напротив, означает согласие с невозможностью преодолеть избыток негативности (р. 195). Впрочем, здесь автор следует за Жижеком, который указывал на невозможность преодоления антагонизма и тоже выводил это из диалектики Гегеля ${ }^{33}$. Тут же прослеживается уже упомянутый ранее отказ от коммунистического мифа. Но главное, что подчеркивается, это необходимость действовать в настоящем, в котором и содержится свобода (р. 196). Настоящим же является государство, от которого, как пишет Жижек, нельзя отойти, если вы не знаете, чем его заменить, а потому следует заставить работать его в негосударственном режиме (р. 197). Это та самая проблема семантического места, о которой говорилось во введении (р. 8), - требующего отрицательной величины, или, по выражению А. Магуна, противо-мысли ${ }^{34}$. Если

32. Ньюман. Указ. соч. С. 63.

33. Жижек С. (1999). Возвышенный объект идеологии / Пер. с англ. В. Сафронова под ред. С. Зимовца. М.: Художественный журнал. С. 13-14.

34. Магун А. (2020). Критики диалектики. Часть 2: Союз реалистов и поэтов против ультрарационализма. URL: https://republic.ru/posts/97399 (дата доступа: 01.08.2021). 
же такую мысль не удается найти, то мы становимся обречены на постоянную замену фигур, стоящих на месте трансцендентного, сдерживающего наши желания ${ }^{35}$, но не исключения самого места.

Выводом из этого следует то, что государство является открытой исторической ситуацией, полной антагонизмов и возможностей (р. 201). Коммунистическая теория государства, таким образом, это теория условий и возможностей создания исторической динамики, способной повлиять на людей. Это практики, направленные на раскрытие автономии, скрытой под границами национальных государств (p. 202-203).

\section{Будущее государства?}

Представленная книга носит явно выраженный политико-философский характер и может быть нелегка для восприятия. Мимо нее, однако, не стоит проходить не-философам, занимающимся государством. Книга будет полезна антропологам, социологам и, что самое главное, юристам, которые своим практико-деформированным взглядом способны внести критические замечания в данную дискуссию. Исключительно философского анализа недостаточно. В осмыслении данного феномена необходимо задействовать представителей всех социогуманитарных наук, поскольку осмысление государства невозможно лишь в одной плоскости и требует междисциплинарного диалога.

Статьи, представленные авторами, могут прочитываться как самостоятельные работы, на которые возможно было бы написать отдельные рецензии, так и быть использованы совместно, с целью выработки уникального метода исследования или принципов новой политики. При чтении неминуемо возникают переклички между главами. Это, однако, не умаляет вклада каждого ученого и самодостаточность каждой работы.

Можно ли говорить о возвращении теории государства? Как указывает Б. Джессоп в книге «Государство: прошлое, настоящее и будущее»: «Рассуждения об отдаленном будущем государства - пустая затея» ${ }^{36}$. Прежде чем строить планы по изменению социальной действительности, необходимо сызнова разобраться в том, как эта социальная реальность, во многом поглощенная сегодня государством, функционирует. Одной теории государства, оторванной от социального универсума, недостаточно. Требуется рассмотрение государства в связи с миром практик, дискурсов, идей, то есть в связи со всем, что производит государство как социальную реальность. Только после этого станут возможны построения проектов будущего с государством или без него. Теория государства, возможно, пока и не вернулась, но данный сборник может быть началом ее долгого путешествия. До тех пор нам необходимо больше подобных книг и исследований, посягающих на сакральный статус государства.

35. Newman. Op. cit. P. 74.

36. Джессоп. Указ. соч. С. 447. 


\section{Bring Back the State}

\section{Mark Belov}

Research Assistant, Centre for Fundamental Sociology, HSE University

Undergraduate Student, School of Law, HSE University

Address: Myasnitskaya str., 20, Moscow, Russian Federation 101000

E-mail: markusabelov@gmail.com

Book Review: Artemy Magun (ed.), The Future of the State: Philosophy and Politics (Lanhmam: Rowman \& Littlefield, 2020). 